\title{
The Next Wave of Corporate Medicine -- How We All Might Benefit
}

\section{Citation}

Cutler, David. 2009. The next wave of corporate medicine -- how we all might benefit. New England Journal of Medicine 361(6): 549-551.

\section{Published Version}

doi:10.1056/NEJMp0904259

\section{Permanent link}

http://nrs.harvard.edu/urn-3:HUL.InstRepos:5346351

\section{Terms of Use}

This article was downloaded from Harvard University's DASH repository, and is made available under the terms and conditions applicable to Open Access Policy Articles, as set forth at http:// nrs.harvard.edu/urn-3:HUL.InstRepos:dash.current.terms-of-use\#OAP

\section{Share Your Story}

The Harvard community has made this article openly available.

Please share how this access benefits you. Submit a story.

\section{Accessibility}


The Next Wave of Corporate Medicine - How We All Might Benefit

David M. Cutler, Ph.D.

The thought of "corporate medicine" makes patients and providers panic.

Medicine is individualistic; corporations are not. Doctors look out for patients; corporations make money. And yet the economic fundamentals are almost certain to increase the importance of corporate medicine. But this time, there is a twist: providers and patients alike can benefit from the changes that are afoot.

The economic crisis is taking a large toll on health care: the number of Americans without health insurance is increasing; Medicaid payments are decreasing; and hospital endowments have plummeted with the stock market. But the problems in medical care go well beyond the current recession. Even before the recession hit, estimates suggested that the number of uninsured people in this country would rise by $20 \%$ in the next decade. ${ }^{1}$ Meanwhile, one third of hospital beds are unfilled, despite a $40 \%$ reduction in the number of hospital beds per capita since the early 1980 s. And the tax-exempt status of not-for-profit institutions comes under periodic scrutiny.

The long-run outlook for hospitals is bleak. One quarter of U.S. hospitals are in the red. ${ }^{2}$ If revenue were to fall by even $2 \%$, another $11 \%$ of hospitals would go from profitable to unprofitable. Other businesses facing such a poor outlook would raise their prices. But Medicare and Medicaid reimbursement — nearly half the business cannot be negotiated. And private insurance prices have plateaued, after a few years of increase. 
Cutting costs is a second option. Hospitals are already laying off nurses, cutting salaries, and postponing major purchases of capital equipment. ${ }^{3}$ But these adjustments are only temporary. There are fixed costs in plant and equipment that cannot be reduced and a host of new priorities on the horizon, from the latest imaging equipment to investment in computer systems. Financially strapped hospitals will need another course of action.

There are, in theory, two choices: hospitals can close, or they can merge with other hospitals. Hospital closure has become the quiet reality. About $15 \%$ of acute care hospitals have closed in the past 25 years. But this is not a viable option for the long term. There are 30\% more emergency-room visits today than there were in 1991, despite a $10 \%$ decrease in the number of emergency rooms. As a result, half of all hospitals, including two thirds of urban hospitals, report that their emergency department is at or over capacity. The situation will become intolerable if emergency access deteriorates further.

In practice, then, mergers are the only option. And in fact, the merger revolution has been proceeding in parallel with the parade of closures. Half of all hospitals are now part of hospital systems. These systems, often anchored by large teaching hospitals, account for $22 \%$ of hospital admissions in the largest metropolitan areas and an even greater share of profits (see table). Big hospitals get higher reimbursement rates, have loyal physicians who keep their beds full, and can invest more in new facilities and equipment.

The trend, then, will be for financially strapped institutions to seek to merge with their bigger cousins. The question for physicians and policymakers is what to do about 
this trend. Antitrust policy has traditionally been built on a certain wariness of large provider groups, with a preference for competition rather than consolidation. But opposing the coming merger wave is not an option, because accepting the unplanned failure of more institutions is not realistic. Far better is to ask the question: as the big institutions absorb their failing competitors, what should we ask of them?

There are three ways such mergers could benefit patients and the medical system as a whole. First, big institutions need to become health centers, not just hospital centers. A hospital system that accounts for a quarter of the market must do more than manage the care of the patients who come through its doors. It must guarantee an adequate supply of primary care everywhere in the community and ensure appropriate access to emergency care. In a way, big health systems will replace state and county health departments, whose budgets have been cut to the bone.

Second, the big health systems need to modernize the health care infrastructure throughout the community. Most big hospitals are investing in information technology in their own institutions. They need to extend this effort beyond their walls. Large, profitable institutions must commit to wiring every doctor's office and clinic, ensuring interoperability of systems, and facilitating the use of clinical decision aids.

Third, the big institutions need to commit to driving down the cost of care. We tolerate waste in medical care in part because no single institution is in charge. As big institutions get bigger, that will change. There are many ways that health systems can drive down costs. They can work with clinicians to develop less expensive care processes, such as substituting nurses for physicians when possible; they can eliminate 
medication errors and other costly mistakes; and they can ensure better management of chronic care.

These changes will not happen automatically. About one third of the U.S. population lives in rural or small urban areas where one hospital often dominates the market, yet health care is not better or significantly cheaper in those areas. Clearly, some intervention is required.

Setting specific, measurable goals for community health and medical care is the first step. The goals might lie along several axes: access (the lengths of acceptable delays in emergency rooms or in scheduling of appointments), process of care (the proportion of patients whose care conforms to set standards), technology (adherence to deadlines for wiring the medical system), and outcomes (reductions in the rates of death or disability from certain causes). The goals need to be agreed on by the provider and public health communities and measured over time.

Payment systems then need to incorporate these goals. State governments, through the Medicaid program, can work with private insurers and possibly the federal Medicare program to formulate alternative compensation arrangements for providers. These might include bonuses associated with providers' meeting of process and outcome goals, shared savings models that reward providers for health improvements in their patient population, and global or episode-based payment in place of fee-forservice payment. The specific compensation arrangements would be negotiated among health systems, governments, and private insurers. But having specific community goals and a dominant health care system would allow reimbursement changes to have the maximum impact. 
A health system configured along these lines would be very different from corporate medicine of the past. Doctors would be integral to making such health systems work; they would not be dictated to by unaccountable corporatations. Patient

preferences would be expressed through physicians and the political representatives in the communities they live in. In many ways, such a system would be closer to a singlepayer system than to a traditional corporate model. And it might just work to make health care better for everyone.

Dr. Cutler is a professor of economics at Harvard University, Cambridge, MA.

References

1. Congressional Budget Office, Key Issues in Analyzing Major Health Insurance Proposals, Washington, D.C.: Congressional Budget Office, December 2008.

2. American Hospital Association, "Trends Affecting Hospitals and Health Systems: 2008 Chartbook", http://www.aha.org/aha/research-and-trends/chartbook/index.html. 3. American Hospital Association, "Report on the Economic Crisis: Initial Impact on Hospitals", November 2008. 
The Size of Large Health Systems

\begin{tabular}{|c|c|c|}
\hline \multirow[b]{2}{*}{$\begin{array}{l}\text { Hospital Referral } \\
\text { Region }\end{array}$} & \multicolumn{2}{|c|}{ Largest System } \\
\hline & $\begin{array}{c}\text { Percent of } \\
\text { admissions }\end{array}$ & $\begin{array}{l}\text { Percent } \\
\text { of profits }\end{array}$ \\
\hline Los Angeles & $11 \%$ & $\wedge$ \\
\hline Houston & $18 \%$ & $25 \%$ \\
\hline New York & $22 \%$ & $58 \%$ \\
\hline Atlanta & $12 \%$ & $15 \%$ \\
\hline Boston & $23 \%$ & $56 \%$ \\
\hline East Long Island & $31 \%$ & $34 \%$ \\
\hline Philadelphia & $20 \%$ & $34 \%$ \\
\hline Dallas & $19 \%$ & $37 \%$ \\
\hline St. Louis & $25 \%$ & $47 \%$ \\
\hline San Diego & $24 \%$ & $40 \%$ \\
\hline Pittsburgh & $29 \%$ & $54 \%$ \\
\hline Orange Co., CA & $23 \%$ & $45 \%$ \\
\hline Minneapolis* & $26 \%$ & $14 \%$ \\
\hline Columbus, $\mathrm{OH}$ & $28 \%$ & $52 \%$ \\
\hline Miami & $19 \%$ & $41 \%$ \\
\hline \multicolumn{3}{|l|}{$\begin{array}{l}\text { Average among } \\
\text { the } 82 \text { regions } \\
\text { with at least } 1\end{array}$} \\
\hline million people & $28 \%$ & $35 \%$ \\
\hline $\begin{array}{l}\text { ^ Hospital profits a } \\
\text { the physician grou } \\
\text { * One hospital sys } \\
\text { profits, but a small }\end{array}$ & not different & $\begin{array}{l}\text { ted from } \\
\text { ssions. }\end{array}$ \\
\hline
\end{tabular}

